\title{
Forecasting Agroforestry Ecosystem Services Provision in Urban Regeneration Projects: Experiences and Perspectives from Milan
}

\author{
Ambrogio Zanzi ${ }^{1, *(D)}$, Federico Andreotti ${ }^{2,3,4}\left(\mathbb{D}\right.$, Valentina Vaglia ${ }^{1} \mathbb{D}$, Sumer Alali ${ }^{1}$, Francesca Orlando ${ }^{5}(\mathbb{D})$ and \\ Stefano Bocchi ${ }^{1}$ (D)
}

1 Department of Environmental Science and Policy, 20133 Milano MI, Italy; valentina.vaglia@unimi.it (V.V.); sumer.alali@unimi.it (S.A.); stefano.bocchi@unimi.it (S.B.)

2 Laboratory of Geo-Information Science and Remote Sensing, Wageningen University and Research, 6708 PB Wageningen, The Netherlands; federico.andreotti@outlook.com

3 CIRAD, SENS, F-34398 Montpellier, France

4 SENS, CIRAD, IRD, Université Paul-Valéry Montpellier 3, University of Montpellier, F-34090 Montpellier, France

5 Department of Molecular and Translational Medicine, Università degli Studi di Brescia, 25121 Brescia, Italy; francesca.orlando@associazione-aida.org

* Correspondence: ambrogio.zanzi@unimi.it

Citation: Zanzi, A.; Andreotti, F.; Vaglia, V.; Alali, S.; Orlando, F.; Bocchi, S. Forecasting Agroforestry Ecosystem Services Provision in Urban Regeneration Projects: Experiences and Perspectives from Milan. Sustainability 2021, 13, 2434. https://doi.org/10.3390/su13052434

Academic Editor: Pasquale De Toro

Received: 31 December 2020

Accepted: 19 February 2021

Published: 24 February 2021

Publisher's Note: MDPI stays neutral with regard to jurisdictional claims in published maps and institutional affiliations.

Copyright: (c) 2021 by the authors. Licensee MDPI, Basel, Switzerland. This article is an open access article distributed under the terms and conditions of the Creative Commons Attribution (CC BY) license (https:// creativecommons.org/licenses/by/ $4.0 /)$.

\begin{abstract}
The expansion of urban agglomerates is causing significant environmental changes, while the demand and need for sustainability keep on growing. In this context, urban and peri-urban agriculture can play a crucial role, mainly if associated with an agroecological approach. Indeed, the extensive use of living fences and tree rows can improve the environmental quality, assuring ecosystem services (ES), developing a sustainable urban food system and increasing local productions and the related socio-economic improvements. This study aims to assess the benefits of an agroecological requalification of a dismissed peri-urban area in the South Milan Agricultural Regional Park (Italy), by evaluating two possible scenarios, both involving planting trees and shrubs in that area. The software I-Tree Eco simulates the ecosystem services provision of planting new hedgerows, evaluating the benefits over 30 years. The study underlines the difference between the two scenarios and how the planted area becomes an essential supplier of regulating ecosystem services for the neighbourhoods, increasing carbon storage and air pollution removal. Results were then analysed with a treemap, to better investigate and understand the relationship between the different ecosystem services, showing a notable increase in carbon sequestration at the end of the simulation (at year 30). The study shows a replicable example of a methodology and techniques that can be used to assess the ES in urban and peri-urban environments.
\end{abstract}

Keywords: regulating ecosystem services; peri-urban agriculture; urban sustainable regeneration; Italy

\section{Introduction}

Due to the continuous urbanisation process, natural environments face severe consequences, such as biodiversity loss and general degradation of natural resources [1]. Agenda 2030 - a call to action for people, planet and prosperity-strongly underlines this trend, and it aims at pursuing 17 Sustainable Developments Goals and 169 targets within 15 years. These objectives seek to realise all human rights, balancing the three dimensions of sustainable development: the economic, social and environmental ones [2]. Recent decades have experienced significant socio-economic changes, headed amongst all by the increasing migration from rural to urban areas: since 2008, more than half of the world's population lives in cities, and by 2050, this percentage will grow up to $70 \%$ [3], compared to only $13 \%$ in 1900 [4]. 
Furthermore, urban areas use $75 \%$ of the available natural resources, even if they occupy just $2 \%$ of the Earth's surface [5]. This situation, which often took place without any regulatory plan, represents one of the main challenges to be addressed [6]. Indeed, urban growth, especially in poor and developing countries, can cause overwhelming problems, such as the continuous increase of slum populations, inequalities, underemployment, pollution, traffic congestion, loss of urban green spaces, sprawl and high demand for services and infrastructures [7], which rarely can be satisfied. Therefore, to avoid these consequences and that urban development results in total degradation of natural resources and a complete loss of ecosystems, it appears that finding new ways for sustainable urban development is crucial to reach the goals defined in Agenda 2030 [2].

In this context, urban and peri-urban agriculture can help to improve liveability, by providing several ecosystem services (ES): urban food production contributes to the protection of natural resources and guarantees several ES (e.g., regulation of water cycles, soil formation and nutrient cycling) [8].

Starting from these assumptions, it becomes apparent that there is a compelling need for further research in order to enrich the knowledge and the available tools to better plan and manage territorial resources and improve sustainability.

\subsection{Urban Regeneration Projects, Agroecology and Agroforestry}

Urban redevelopment projects can provide ES, resource efficiency and foster urban regeneration, particularly in underused areas [9]. The recovery of peri-urban areas is a typical example of good practices to implement [10] land resources in cities. In this context, agriculture redevelopment projects that might include green infrastructure (GI) allow the regeneration of peri-urban tissues, thanks to different new niches and ecosystems, suitable in urban and peri-urban environments [11]. The advantages for people living in GI cities are the deliveries of ES to residents, which can significantly improve the cities' quality of life [9].

As already affirmed in recent literature, several examples of municipalities aim to enhance the environmental and social quality of life and invest considerable financial capital in restoring or creating natural capital [12-16]. These examples survey the USA scenario, where municipal GI programs are focusing on pursuing the Clean Water Act standards [17] to reduce the rate and volume of stormwater run-off, thus improving water quality. Many urban areas are also suffering from the effects of poor air quality [18]. For example, considering the high levels of PM10 in the air, many research studies underline the importance and the contribution of urban and peri-urban green areas to mitigate local air quality issues [19-21], mainly thanks to tailored planning and management of urban and peri-urban forests. Urban and peri-urban forests' contribution to improving air quality has a role in Italian cities and peri-urban areas too [22], with a particular interest in $\mathrm{O}_{3}$ and PM10.

Furthermore, agroforestry can provide multiple ES, acting simultaneously on: carbon sequestration; soil enrichment; biodiversity conservation, air, and water quality improvement [23].

Our case study focuses on a peri-urban area at the fringe zone between Milan and the southern agricultural park (Italy). The urban sprawl phenomenon is typical in this context, and GI implementation fosters the importance of permeable and vegetated soil surfaces for retaining, detaining, and infiltrating stormwater [24,25]. The GI sites could include urban and peri-urban zones, natural and human-made habitats such as parks, green roofs, rain barrels, bioswales, street trees, permeable pavers, and community gardens [24-26].

This study associates GI sites' concept to peri-urban agriculture and agroforestry; and evaluates the contribution of a living network of trees and shrubs in the provision of ES, focusing on the regulating ones and particularly on $C$ storage, $C$ sequestration and other ES related to air quality.

Moreover, the research emphasises the concept of GI sites as structures able to provide benefits to urban, peri-urban greens spaces and natural areas, with a multifunctional 
role, mainly referring to the importance of interconnections between habitats [27]. In a neglected peri-urban area, GI - well planned, developed and maintained-can enhance the surrounding urban landscapes by providing natural capital $[9,28]$. Cities worldwide have to face challenges related to the sustainability of their habitat for citizens because of the limited space availability and ecological preservation. For these reasons, we investigate GI's role that combines urban requalification with rational land use to enhance ES provision.

The innovative role that GI can also play in urban and peri-urban agriculture context is that they represent an essential instrument to increase biodiversity and complete the agricultural landscape, such as with the proper implementation of hedges and rows agroecological approach.

As it is known, agroecology comprehends the area of intersection of scientific disciplines based on ecology with technological innovations related to the agri-food system with social and political issues. It also covers the scientific concepts and principles applied to design and manage agri-food systems in a sustainable way. It offers the concept of the integrated study of the agri-food system's ecology, including ecological, economic and social dimensions [29].

Agroecology aims at maximising the ES offered by agricultural systems and agrifood supply chains, starting from production (e.g., food, fibres, materials) and regulation services, with particular reference to water (Figure 1). For these reasons, it is clear that an agroecological approach fits well with the needs of urban agglomerates, where the need for food goes hand in hand with the needs of ES.

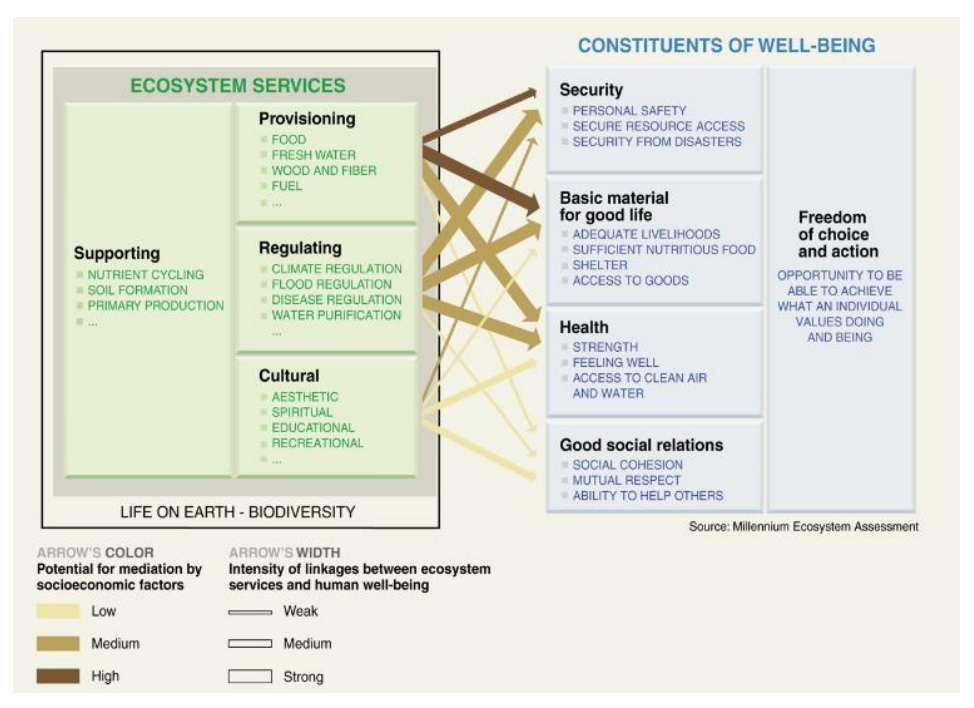

Figure 1. Ecosystem services and their classification-Millennium Ecosystem Assessment, 2005.

The peri-urban context within GI and the agroecological approaches are crucial for reaching a high ES provision level for the environments. One approach can also be agroforestry. This includes agricultural systems and techniques where herbaceous crops, woody species and/or animals are on the same unit of an agricultural surface according to a rational spatial distribution and a specific temporal sequence [30]. Therefore, it concerns agricultural land use by maintaining or introducing single trees or a mix of woody perennial species within cultivated fields to benefit from positive ecological interactions and practical economic implications.

Agroforestry systems contribute to the objectives identified in the Europe 2020 strategy for smart, sustainable and inclusive growth in the following ways: biomass production, improvement of the quality of the groundwater by slowing the leaching of nitrates, erosion control by providing permanent coverage of the soil, better adaptation and mitigation of the effects of climate change, prevention of fire damage in forests and limitation of irrigation 
use. FAO has highlighted the agroforestry issue by including it as a fundamental policy action for the environment and has published a specific guide for decision-makers [31].

Agroforestry systems help promote resource efficiency and support an agricultural economy based on ES. Therefore, the agroforestry role in supplying numerous ES is crucial for integrating trees in herbaceous agricultural systems, implementing a potential sustainable land-use system that combines production with natural resources conservation in temperate regions [25].

This case study focuses on the territorial scale, to assess the provisioning of ES thanks to the presence of GI connection systems between roads, waterways, fields, agroforestry systems and city suburbs.

\subsection{ES Assessment Tools}

Several researchers have focused their work on developing tools, instruments-mainly models - and frameworks, useful to evaluate the impact of environmental regeneration projects and their return in terms of provided ES. Indeed, decision-makers and stakeholders need instruments capable of forecasting the impact and the consequences of their choices, and these models can represent a productive tool for them to have reliable predictions [32]. Therefore, as this research field is gaining attention, there is a higher demand for tools capable of evaluating and forecasting each requalification choice's impact, affecting policy decisions [33-35]. As in other scientific disciplines, these tools are specific models, capable of assessing and forecasting spatially explicit information outputs about ES provision. In the last few years, different tools could be used to assess ES. They are usually freely available: the major ones—such as InVEST (Integrated Valuation of Ecosystem Services and Trade-offs), ARIES (ARtificial Intelligence for Ecosystem Services), EVT (Ecosystem Valuation Toolkit), and I-Tree ECO-have been tested in different environments and were used to conduct multiple peer-reviewed papers [36], as it emerges from several studies [19-21,37].

Therefore, only with reliable tools and instruments can it be possible to conduct ES assessment and forecast, useful to support the decision-making process. This activity is now possible by choosing the most appropriate tool available, depending on the particular needs, data and requests.

\subsection{Objectives:}

Starting with these assumptions, the goals of the present study are to:

(i) assess and quantify the ES provided by two possible and alternative requalification scenarios;

(ii) estimate the impact of these scenarios, analysing the ES provision in the next 30 years;

(iii) explore the relationship of the ES's provision in the two alternatives, thanks to the treemap analysis, to understand and underline the pros and cons of each requalification choice.

\section{Materials and Methods}

\subsection{Case Study}

In the analysed case study, we quantify and assess ES's provision by a peri-urban requalification. This requalification focuses on implementing a GI consisting of a net of trees and shrubs within peri-urban agricultural fields, following an overall agroecological approach-primarily intended to connect rural areas with the urban ones providing several ES. The requalification project took place in the south part of Milan (Figure 2). 


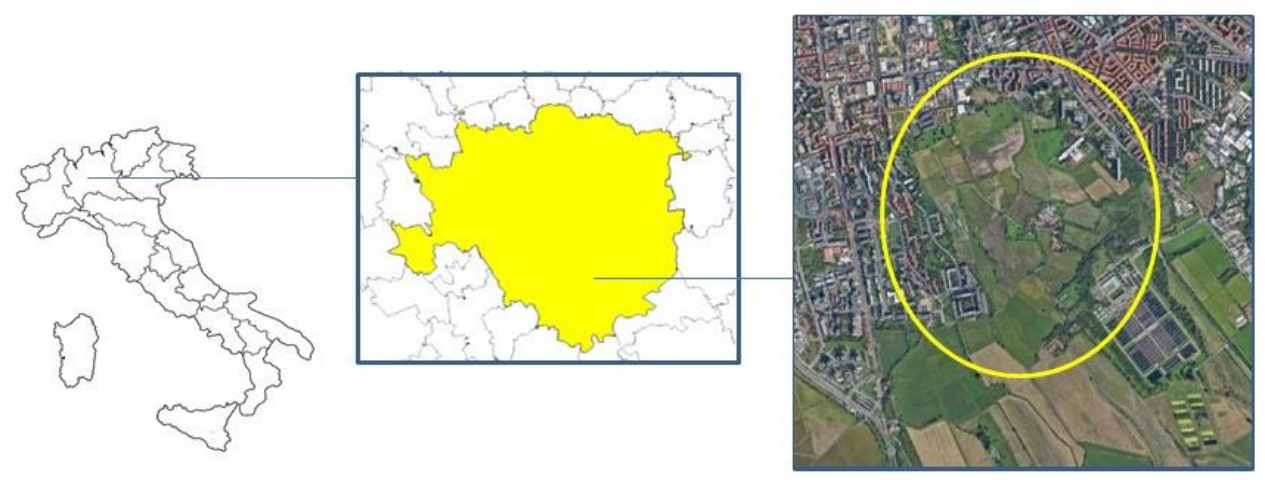

Figure 2. The area of the case study, situated in the peri-urban area of Milan, Italy.

This city has a 23\% (4231.74 ha) of its territory in South Milan Agricultural Regional Park, which is part of a plan of protection and enhancement for all the elements that characterise the agricultural landscape. This Agricultural Park forms a denser city contour, along the town's southern arch, providing a more dynamic agricultural economy and less favourable infrastructural conditions. The continuity of the agrarian territory characterises the horizons of the low Lombardy plain.

Within the municipality of Milan, the landscape component expressed by the agricultural territory necessarily has a limited but not less significant extension, both in terms of the preservation of memory and the historical, or rather original, characters of the urban context, both under the role that is now sustainable by the peri-urban open spaces towards a demand for quality of the environment and expectations for a renewed relationship with agricultural production expressed by citizens.

In this context, the project-named Milano Porta Verde (MPV)—collects the legacy of the European project "OpenAgri", aiming to extend its lifespan till 2030. In 2017, the Municipality of Milan launched the "OpenAgri-New Skills for New Jobs in Periurban Agriculture" project. Together with 16 partners, the Municipality of Milan had been awarded in the "Urban Innovative Actions" call, funded by the European Regional Development Fund (ERDF), to fund innovative proposals that address urban issues, such as environmental and socio-economic problems. The project was finished in 2020 and focused on innovative ideas to face urban challenges relevant to the future by creating a new innovative agricultural centre, worth 6 million euros.

As OpenAgri, the MPV project wants to experiment with new territorial development models that conceive the city and the countryside as a single organism and stage the possible paths towards sustainability of human settlement and food production, improving local citizens' well-being impoverishing life in the soil. The interested peri-urban area could be an agroecological pioneer project open to the territory by creating a link between the human community and food production in a sustainable environment. The project lays the foundations for creating, through a participatory approach, an agroforestry park, which aims to be productive, experimental, demonstrative and didactic. The project stages a pilot experience of a new paradigm of agriculture, environment, landscape, and society, parallel with similar European Network experiences: the MPV has already been named as a notable case study within the European "Liaison" framework as an ambitious pilot project of European Rural Innovation Ambassadors [38].

This proposal adds to agriculture the typical advantages of complex forest systems becoming an urban regenerative agricultural centre, which aims to be one of Europe's first experiences of a peri-urban experimental approach to an agroforestry system. The primary production function of food sources takes place together with the generation of ES connected with biodiversity, carbon sequestration, environmental quality, work and social cohesion, at the same time involving the various territorial subjects in innovative strategies for accessing the food market at zero $\mathrm{km}$, connected to educational and didacticeducational activities. 
The MPV project aims at:

- Regenerating the project area, through the implementation of an agroforestry plan based on a network of living fences constituted of trees and shrubs;

- Incubating the know-how of a pool of innovative start-ups selected from the OpenAgri project, of associations operating in the area and of the Milanese universities;

- Laying the foundations for an open-source digital library of already tested sustainable agricultural practices;

- Testing a new model of economic and financial management of investments in agriculture, with the opening towards the Agricultural Support Communities (CSA);

- Becoming the ideal place to host the experimentation of the most innovative environmental, meteorological and ecological monitoring technologies, in an Open Source IoT context;

- Helping citizens achieve sustainable development goals, facing this millennium's challenges on Food Security and environmental regeneration, with a continuous training and educative approach.

Thanks to the area's ecological rehabilitation, the neighbourhoods' inhabitants will witness the restoration of a peri-urban agricultural area with strong agroecological potential.

\subsection{Data Collection and Database Construction}

The MPV project covers 45 hectares of agricultural fields. Since the overall requalification is at the starting point, we built a database encompassing two different scenarios to run our ES analysis. The first one uses the available information, given by the project proposers, about the tree network's extension and characteristics. Therefore, this first scenario and the following analysis focus on the real project accepted in future planning.

The database for the scenarios includes a network of trees and shrubs, divided into two typologies.

The first scenario (Figure 3) named "Milano Porta Verde Hedgerows" (MPV-H) includes vegetation planted as a single tree and shrubs line, situated on the area's hedges, dividing some fields and the project area from the surroundings. In the MPV-H scenario, trees and shrubs were mainly placed on the fields' hedges traditionally cultivated. The implant line of trees and shrubs considers standard distances: $1.2 \mathrm{~m}$ between plants.

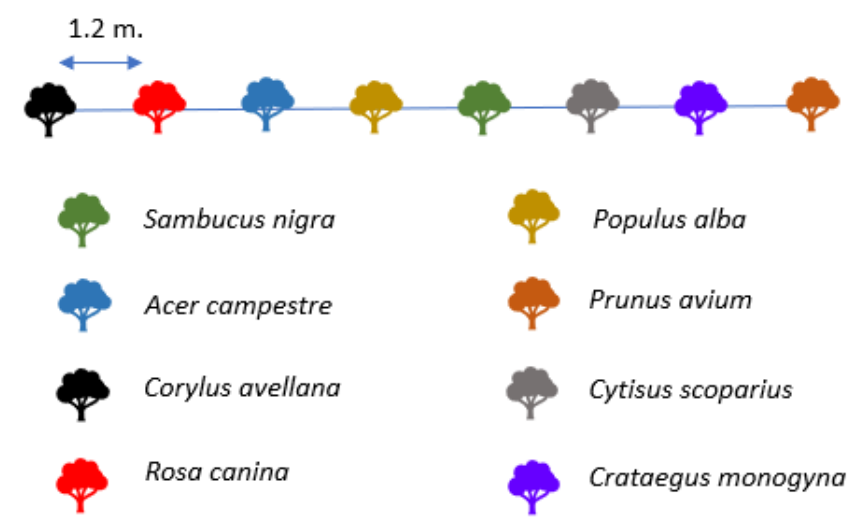

Figure 3. The plantation scheme used in the first scenario (MPV-H), on the single line of trees and shrubs, the distance between elements is $1.2 \mathrm{~m}$.

The second scenario (Figure 4) named "Milano Porta Verde Agroforestry" (MPV-A) includes an alley-cropping system based on an own research proposal simulating the ES provided by implementing a stronger agroforestry plan, taking inspiration from the European literature [39]. In this agroforestry scenario, we propose to cover half of the area-22.5 hectares-with trees and shrubs focusing on a standard plot of $100 \mathrm{~m} \times 100 \mathrm{~m}$. We propose a line of trees and shrubs every $10 \mathrm{~m}$, with a distance between the plants on 
the same line of $4 \mathrm{~m}$, the total number per plot is 250 plants. Moreover, we propose to plant bigger tree-trunk diameters of $2 \mathrm{~cm}$ for shrubs, $4 \mathrm{~cm}$ for trees (Table 1) to have a higher ES level from the beginning of the project.

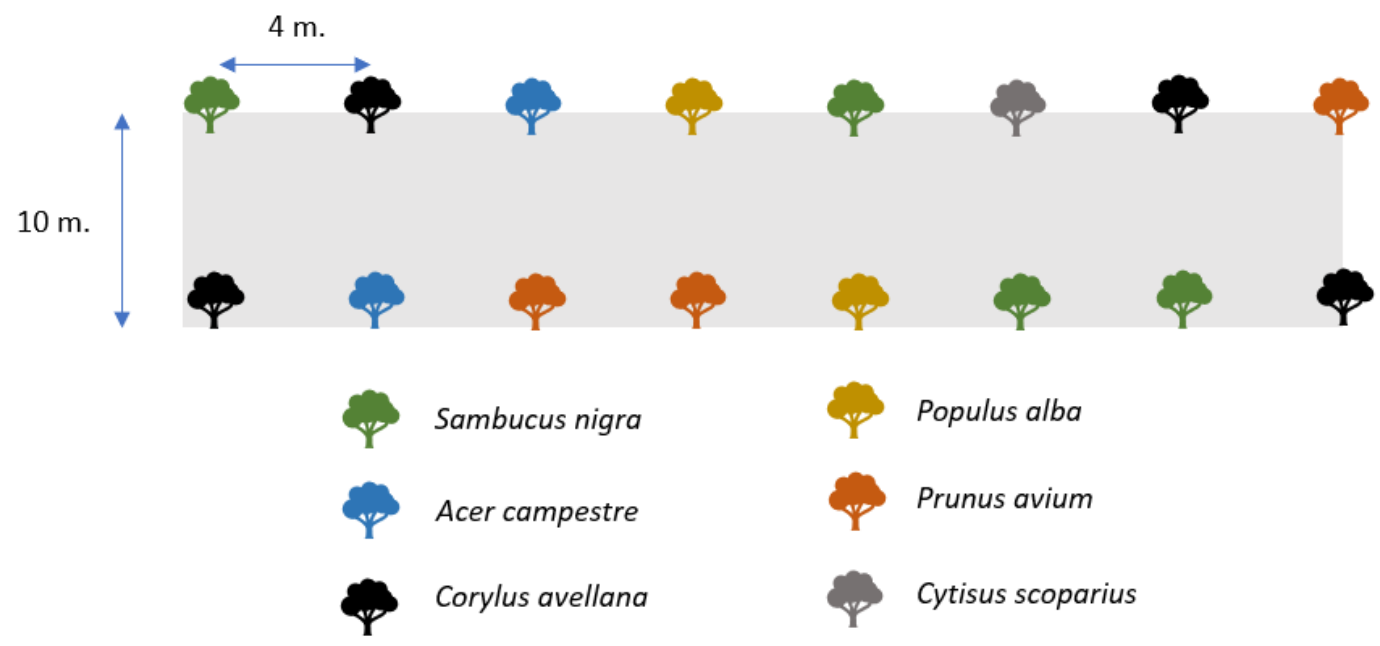

Figure 4. The plantation scheme used in the second scenario (MPV-A). The distances between the lines of trees and shrubs are $10 \mathrm{~m}$, and the distance between each element on the same line is $4 \mathrm{~m}$.

Table 1. Differences between the two analysed scenarios and relative input are useful for running the ES assessment with the selected software.

\begin{tabular}{|c|c|c|c|c|c|c|c|}
\hline & $\begin{array}{c}\text { Distance } \\
\text { between } \\
\text { Plants }\end{array}$ & $\begin{array}{c}\text { Overall } \\
\text { Tree/Shrub } \\
\text { Number }\end{array}$ & $\begin{array}{c}\text { Shrub/Tree } \\
\text { Diameter }\end{array}$ & $\begin{array}{l}\text { Land-Use } \\
\text { Type }\end{array}$ & $\begin{array}{l}\text { Crown Light } \\
\text { Exposure }\end{array}$ & $\begin{array}{c}\text { Health } \\
\text { Parameter }\end{array}$ & $\begin{array}{l}\text { Type of } \\
\text { Position }\end{array}$ \\
\hline $\begin{array}{c}\text { Scenario 1, } \\
\text { MPV-H }\end{array}$ & $1.2 \mathrm{~m}$. & 9260 & $0.5-2 \mathrm{~cm}$. & Agriculture & 4 & $100 \%$ & No street \\
\hline $\begin{array}{c}\text { Scenario 2, } \\
\text { MPV-A }\end{array}$ & $4 \mathrm{~m}$ & 5625 & $2-4 \mathrm{~cm}$. & Agriculture & 5 & $100 \%$ & No street \\
\hline
\end{tabular}

Summing up the adopted decisions to run the simulation with I-Tree Eco model, the main elements of the two considered scenarios are:

1. The same typology of tree and shrubs species. The species are mainly autochthonous plants according to the regional policies. The number of plants and the scheme implant are different in the two scenarios.

2. Identification number (ID), represents the progressive number of the elements. This phase is essential for organising I-Tree Eco model dataset.

3. Land-use type was, by default, set as agriculture land use from the Lombardy Region website. This information is essential for organising the I-Tree Eco model dataset for the meteorological and soil information.

4. In the scenario, MPV-H the height and diameter at breast height (DBH) of each element, are deducted from the actual requalification plan, for the simulation of the second scenario we established measure considering an implant of more developed plants (Table 1; Figures 3 and 4).

5. The information about light exposure of each element was different, considering MPV-H and MPV-A (Table 1).

6. The health parameter of plants was set at the maximum level since all the plant materials come from certified nurseries.

7. The type of position of each element is crucial to simulate tree growth and development, and, due to the plantation scheme, it was set as a non-street tree, with proper space to develop without interferences (Figures 3 and 4). 
Moreover, the two configurations follow a different approach. The first scenario-the one proposed and foreseen in the project papers-is planned to use small-density plants with a higher density of plantation, and trunk diameters vary from $0.5 \mathrm{~cm}$ to $2 \mathrm{~cm}$. This choice is typical of agroforestry and is due to budget limitations too. Conversely, the second configuration uses an already developed tree-trunk diameter of $4 \mathrm{~cm}$, while it has a minor density of elements. This solution represents an interesting alternative to deliver higher ES levels from the beginning of the project.

This information is needed to calculate the ES provided by the tree network and simulate the thirty-year forecasting in the two scenarios.

\subsection{Selected Ecosystem Services}

The MPV—and the previous OpenAgri project—provides a wide range of ES, since it deals with the requalification of an area with several issues, beyond environmental aspects, taking into account the social and the economic needs of the area. Anyhow, in this study, we decide to focus on the regulating ES provided by trees and shrubs. This choice is due to multiple considerations and analysis: first of all, the cultural ES-such as recreational activities, and other social aspects-need a more extended period to be provided and the project is still at a starting point of many initiatives-e.g., a Community Supported Agriculture (CSA) set up-so a broader analysis of socio-economic ES could be completed after their establishment, estimated for at least five years. Moreover, other studies evaluated the LCA impact of the OpenAgri start-up as an impetus for urban regeneration [40].

This study investigates the environmental impact of the area's requalification, focusing on the regulating ES provided by trees and shrubs. Moreover, we analysed the ones linked to the Carbon cycle, air quality, and avoided run-off within the regulating ES set. This selection considers the environmental issues of the urban area where MPV is located. Indeed, Milan is suffering from continuative air pollution problems: the city and surroundings are above the critical level of concentration of each primary air pollutant $\left(\mathrm{O}_{3}\right.$, $\mathrm{NO}_{2}$, PM 2.5 and PM 10), and it is also witnessing a growing percentage of soil sealing, with adverse effects on water management [41].

Therefore, in the light of this focus on the contribution of trees and shrubs to the requalification project and their role in providing ES, we considered I-Tree Eco as the ideal tool among the available software, using the database as input for the software.

This software was specifically developed to help researchers assessing urban and peri-urban forest value and its functions. Several models are included within the software to assess and evaluate the different ES provided by trees and shrubs. Indeed, I-Tree Eco is designed to use standardised data from previously prepared inventory (or available databases, as in this case study), hourly air pollution and meteorological data to quantify urban forest structure and numerous urban forest effects.

The software was firstly used in the US, and it was chosen because of its reliability, state-of-the-art technology, being peer-reviewed and recommended by the USDA Forest Service. I-Tree Eco can assess the structure of the analysed urban and peri-urban forest in terms of species composition, leaf area and biomass, and evaluate the associated regulating ES, such as carbon storage sequestration; air pollutants removed hourly and the avoided run-off. For each of these ES, I-Tree Eco can assign a monetary value, therefore giving an overall value to the database, helping determine its value [42].

The database covers all the minimum requirements needed by I-Tree Eco to simulate and assess the following ES:

- Air Pollution Removal.

Trees and shrubs improve air quality in several ways, such as decreasing air temperature, directly removing pollutants, and reducing energy consumption in buildings, thus providing significant regulating ES to the local environment. I-Tree Eco calculates the amount of ozone $\left(\mathrm{O}_{3}\right)$, sulfur dioxide $\left(\mathrm{SO}_{2}\right)$, nitrogen dioxide $\left(\mathrm{NO}_{2}\right)$, carbon monoxide $(\mathrm{CO})$ and particulates less than 2.5 microns (PM 2.5), removed by the vegetation year after year. 
The removed quantities are estimated using the hourly tree-canopy resistances for ozone, while estimates related to sulfur and nitrogen dioxides are based on a hybrid of big-leaf and multi-layer canopy deposition models [43,44]. Since the absorption of carbon monoxide and PM 2.5 by vegetation is not directly related to transpiration, removal rates (deposition velocities) are calculated using values from the literature [45], then calibrated using leaf phenology and leaf area. Moreover, PM 2.5 removal considers a resuspension rate $(50 \%)$ of particles back to the atmosphere [46]. Indeed, plants absorb PM 2.5 when it is deposited on leaf surfaces [47]. However, this deposited PM 2.5 can be returned into the atmosphere during rain events, dissolved or transferred to the soil. These phenomena can lead to positive or negative pollution removal quantities, depending on various atmospheric factors.

I-Tree Eco bases its analysis on user-defined local pollution. In the present case study, values refer to the nearest meteorological station, in Milano Linate, close to the MPV area.

- Carbon Storage and Sequestration.

As known, woody plants contribute to the mitigation of climate change by sequestering and stocking atmospheric carbon in tissue, thus decreasing the atmosphere's carbon dioxide levels [48].

Carbon storage defines the quantity of carbon accumulated in the above-ground and below-ground parts of woody vegetation. Equations from literature and available tree data show that compared to traditional forest trees, open-grown trees-as the urban and peri-urban ones-tend to have less biomass [49]. In order to consider that difference, biomass results were multiplied by 0.8 . The calculation of the tree dry-weight biomass was the stored carbon by multiplying by 0.5 .

Carbon sequestration is instead defined as the removal of carbon dioxide from the air by plants. To calculate the amount of carbon sequestered annually, I-Tree Eco considers average diameter growth from the proper genera, diameter class and tree condition. These data are added to the existing tree diameter, incrementing tree size step by step each year.

- Oxygen Production.

To quantity the oxygen produced by trees and shrubs in the project, the calculation considers carbon sequestration based on atomic weights: net $\mathrm{O}_{2}$ release $(\mathrm{kg} / \mathrm{yr}$. $)=$ net $\mathrm{C}$ sequestration $(\mathrm{kg} / \mathrm{yr}$.) $\times 32 / 12$. The net carbon sequestration rate is the carbon sequestered due to the annual tree growth and reduced, considering the amount of carbon lost due to tree mortality and decomposition [50].

- $\quad$ Avoided Run-off.

When it rains, water can follow different paths: thanks to the vegetation, it is partly intercepted by trees and shrubs, avoiding the soil's achievement. The water falling to the ground could give away in the soil, either becoming surface run-off or spreading on the ground. In urban areas, the large percentage of impervious and paved surfaces increases the amount of surface run-off. Trees and shrubs can intercept water, thus resulting in decisive in reducing surface run-off. I-Tree Eco calculates the annual avoided surface runoff thanks to trees and shrubs' presence by estimating the quantity of rainfall intercepted by vegetation. In particular, the model is capable of calculating the difference between annual run-off with and without vegetation. I-Tree Eco considers only the amount of water intercepted by the above-ground biomass: this means that the overall avoided run-off might be more significant, since the other factors—e.g., soil cover-affect it.

\subsection{Ecosystem Services Forecasting}

Once evaluated the current ES provision level, in order to understand the tree network's growth and development in the next future and the related ES increase, a simulation was conducted to assess ES provisioning in the next thirty years.

The simulation started using an extension of I-Tree Eco-the i-Tree Forecast modeldeveloped by the USDA Forest Service to assess future changes in urban and peri-urban 
forest structure and function. The tool estimates future changes both in dimension (e.g., diameter) and in condition from the initially given structure. Indeed, it mainly takes into consideration three aspects of tree life: growth, establishment and mortality. Growth is estimated based on several parameters, such as growing season length, species-specific growth rates, tree condition and tree maturity. Tree mortality is estimated using a fixed input mortality rate, considering the optimal condition of the planted trees [51]: this rate can change, and the user can adjust it, and it depends on the starting health condition and the dieback of each tree. Even if it is possible to include in the extreme simulation events - such as bad weather or the presence of parasites-and their impacts on the vegetation and consequently on ES provision, we decided not to insert this possibility, in order to have a clear view of the potential ES provided in the area without any possible interference of external agents, to have an overall comparison between the two analysed scenarios.

\subsection{Treemap}

To better understand the results and the relationships between ES, we tested the treemap methodology. We use an Excel file for immediate space-filling visualisation of the different items' hierarchy to apply the I-Tree Eco results for the treemap [52]. A treemap is usually composed of root rectangles groups that represent the items of the study. The treemap successfully helps to visualise big data [53]. On the other hand, the treemap represents only one future scenario as it represents one moment in time. The possibility of highlighting immediate outliers and the clear hierarchical grouping enabling single scenario evaluation has not been used yet to explore forecasting scenarios.

\section{Results}

\subsection{Provided Ecosystem Services}

I-Tree Eco's results regard the tree population's structure and composition for each studied scenario. They show the quantification of the tree cover, leaf area and leaf biomass provided by the trees and shrubs in the area. In the MPV-H scenario, the predominant species are Sambucus nigra, Salix caprea and Rosa canina, respectively with $11 \%, 10.2 \%$ and $9.5 \%$ of the total population (9260 elements). Trees cover about 3308 hectares and provide 8611 hectares of leaf area. However, the population percentage does not correspond to an equal percentage of leaf area (Table 2), as it emerged from the results due to each species' particular biological and morphological characteristics.

Table 2. The principal species present in the first scenario, with a percentage of the population and correspondent leaf area.

\begin{tabular}{ccc}
\hline Species Name & Percentage of Population (\%) & Percentage of Leaf Area (\%) \\
\hline Sambucus nigra & 11.0 & 18.4 \\
\hline Rosa canina & 9.5 & 9.0 \\
\hline Acer campestre & 7.4 & 10.4 \\
\hline Prunus spinosa & 8.2 & 8.4 \\
\hline Salix caprea & 10.2 & 5.2 \\
\hline Crataegus monogyna & 6.7 & 5.5 \\
\hline Cytisus scoparius & 4.9 & 6.0 \\
\hline Viburnum opulus & 3.4 & 7.4 \\
\hline Quercus robur & 4.4 & 3.8 \\
\hline Corylus avellana & 3.3 & 4.4 \\
\hline
\end{tabular}

On the other hand, the second scenario was assumed to use more plant elements (Table 3), occupy a greater soil area, and, at the same time, have less density of plants on 
the rows. This scenario's implementation-5625 plants-would assure a similar tree cover (3.29 ha) and leaf area (9.81 ha) (Table 4).

Table 3. The principal species present in the second scenario, with percentage population and correspondent leaf area.

\begin{tabular}{ccc}
\hline Species Name & Percentage of Population (\%) & Percentage of Leaf Area (\%) \\
\hline Sambucus nigra & 16.0 & 19.2 \\
\hline Acer campestre & 12.0 & 14.9 \\
\hline Cytisus scoparius & 12.0 & 13.7 \\
\hline Corylus avellana & 12.0 & 13.4 \\
\hline Prunus spinosa & 8.0 & 7.7 \\
\hline Populus alba & 8.0 & 3.1 \\
\hline Quercus robur & 4.0 & 3.2 \\
\hline Fraxinus angustifolia & 4.0 & 3.0 \\
\hline
\end{tabular}

Table 4. Comparison between the ecosystem services (ES) provided at year 0 by the two different alternative scenarios.

\begin{tabular}{cccccccc}
\hline & Tree Cover & Leaf Area & C Storage & C Sequestration & $\begin{array}{c}\text { Air Pollution } \\
\text { Removal }\end{array}$ & $\begin{array}{c}\text { Avoided } \\
\text { Run-Off }\end{array}$ & $\begin{array}{c}\text { Oxygen } \\
\text { Production }\end{array}$ \\
\hline $\begin{array}{c}\text { Scenario 1, } \\
\text { MPV-H }\end{array}$ & 3.308 ha & 8.611 ha & $1.165 \mathrm{t}$ & $1.212 \mathrm{t} /$ year & $123 \mathrm{~kg} /$ year & $264.6 \mathrm{~m}^{3} /$ year & $3.233 \mathrm{t} / \mathrm{year}$ \\
\hline $\begin{array}{c}\text { Scenario 2, } \\
\text { MPV-A }\end{array}$ & 3.296 ha & 9.81 ha & $7.8 \mathrm{t}$ & $5.59 \mathrm{t} /$ year & $128 \mathrm{~kg} /$ year & $286.9 \mathrm{~m}^{3} / \mathrm{year}^{2}$ & $14.91 \mathrm{t} / \mathrm{year}$ \\
\hline
\end{tabular}

- Air Pollution Removal:

Regarding the air pollution removal, the removed pollutant's level depends on tree size and the abundance of the pollutant in the air. For example, if trees are close to a street, thus with a high presence of particulate, the trees will tend to absorb more while growing; while if they are in a less polluted area-e.g., countryside or a park-the level of pollutant at microscale will be minor; therefore, the overall assumption will not increase as much. In our case study, the peri-urban forest is in an agricultural area, with a low air pollutant presence at the micro-scale. Indeed, I-Tree Eco uses "Agriculture" as a land-use type.

Pollution removal by trees was estimated using the database and the recent available pollution and weather data available from Milan Linate Airport weather station. Ozone was the most removed pollutant. In the first scenario, the agroecological net of trees and shrubs removes a total of $123 \mathrm{~kg}$ of air pollutants per year, encompassing ozone $\left(\mathrm{O}_{3}\right)$, carbon monoxide $(\mathrm{CO})$, nitrogen dioxide $\left(\mathrm{NO}_{2}\right), \mathrm{PM} 2.5$, and sulfur dioxide $\left(\mathrm{SO}_{2}\right)$. Moreover, the vegetation emits an estimated $47.15 \mathrm{~kg}$ of volatile organic compounds (VOCs) $-41.81 \mathrm{~kg}$ of isoprene and $5341 \mathrm{~kg}$ of monoterpenes. The species that tend to emit higher VOC levels are Salix caprea and Quercus robur: emissions vary among species due to species characteristics and leaf biomass.

In the other scenario, the agroforestry network can remove $128.5 \mathrm{~kg}$ per year of overall pollutants, while producing $62.58 \mathrm{~kg}$ per year of VOCs.

- Carbon Storage and Sequestration:

Trees reduce the amount of carbon in the atmosphere by sequestering carbon in new growth every year. The amount of carbon annually sequestered can increase as far as the tree's dimension and health increase. In the first case, I-Tree estimates the gross sequestration equal to 1212 metric tons of carbon per year, while in the second one, the estimation is equal to 5.59 tons per year. 
Regarding carbon storage, the first scenario stored 1.16 metric tons of carbon. Of the species sampled, Acer campestre stores the most carbon (approximately $10.6 \%$ of the total carbon stored), and Sambucus nigra sequesters the most (approximately $10.5 \%$ of all sequestered carbon). The second one can store 7.8 ton. of carbon, mainly thanks to a more significant dimension of the trees and related bigger trunk diameter.

- Oxygen Production:

Oxygen production is one of the most known benefits of trees. The tree's annual oxygen production is directly related to the amount of carbon sequestered by the tree, tied to tree biomass accumulation. In our study, the first scenario is estimated to produce 3233 tons of oxygen per year, while the alternative produces 14.91 tons per year.

- $\quad$ Avoided Run-off:

Trees and shrubs intercept precipitation, while their root systems promote infiltration and storage in the soil. Avoided run-off is estimated based on local weather from the user-designated weather station, Milan Linatem, for both scenarios. In the first case, the trees and shrubs help to reduce the run-off by an estimated 265 cubic meter per year; meanwhile, the contribution is 286.9 cubic meter per year in the second scenario.

\subsection{Ecosystem Services Forecast}

After quantifying the provided ES at the planting time, we focused on understanding how the peri-urban forest could contribute in terms of ES in the next thirty years, and which configuration could guarantee a higher ES level in the future.

Using the I-Tree Eco model's forecasting extension with the described parameters, we simulated several parameters and ES. Some of these (e.g., tree cover, leaf area, leaf biomass) refer to the vegetation growth and development; other are linked to ES provision (C storage and sequestration, removal of $\mathrm{O}_{3}, \mathrm{NO}_{2}$ and $\mathrm{SO}_{2}$ ).

In general, as trees and shrubs grow, the environmental benefits increase too, resulting in an improvement of ES levels. Anyhow, in our case study, it is interesting to quantify the differences between the two scenarios in the next thirty years (Table 5).

Table 5. Comparison between the ES provided at year 30 by the two different alternative scenarios.

\begin{tabular}{cccccccc}
\hline & Tree Cover & Leaf Area & C Storage & C Sequestration & $\begin{array}{c}\mathrm{NO}_{2} \\
\text { Removal }\end{array}$ & $\begin{array}{c}\mathrm{SO}_{2} \\
\text { Removal }\end{array}$ & O $_{3}$ Removal \\
\hline Scenario 1 & $4.6 \mathrm{ha}$ & $11.31 \mathrm{ha}$ & $72.69 \mathrm{t}$ & $4.48 \mathrm{t} /$ year & $38.9 \mathrm{~kg} /$ year & $7.8 \mathrm{~kg} /$ year & $109.5 \mathrm{~kg} /$ year \\
\hline Scenario 2 & $9.76 \mathrm{ha}$ & $62.67 \mathrm{ha}$ & $478.5 \mathrm{t}$ & $29.86 \mathrm{t} /$ year & $95.4 \mathrm{~kg} /$ year & $18.8 \mathrm{~kg} /$ year & $266.4 \mathrm{~kg} /$ year \\
\hline
\end{tabular}

\subsection{Treemap}

We visualised the results related to $\mathrm{O}_{3}, \mathrm{NO}_{2}, \mathrm{SO}_{2}$, leaf area, leaf biomass, tree cover and $\mathrm{C}$ sequestration presenting the comparison between year 0 and 30 by the treemap (Figure 5) each of the analysed solution. The comparison of the two times showed clear results related to outliers and temporal trend of growth. Outliers are represented as $\mathrm{O}_{3}$ in Year 30 and Year 0; and C sequestration for year 30 and Year 0 . On the other hand, the treemap allows us to see how the indicators remain stable, excluding one: $\mathrm{C}$ sequestration, which has a considerable increase at Year 30. 
Scenario MPV-H

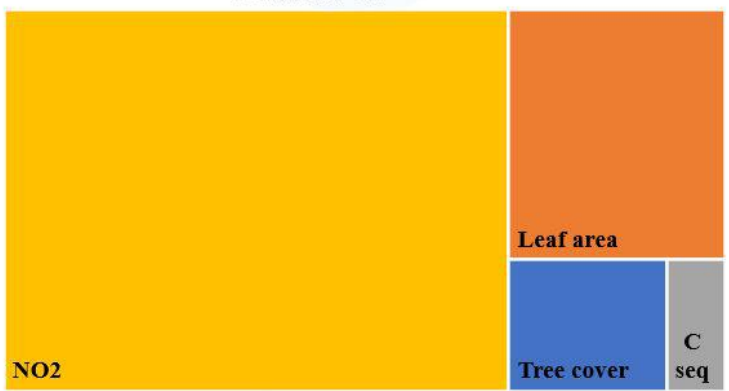

Scenario MPV-H - Forecast

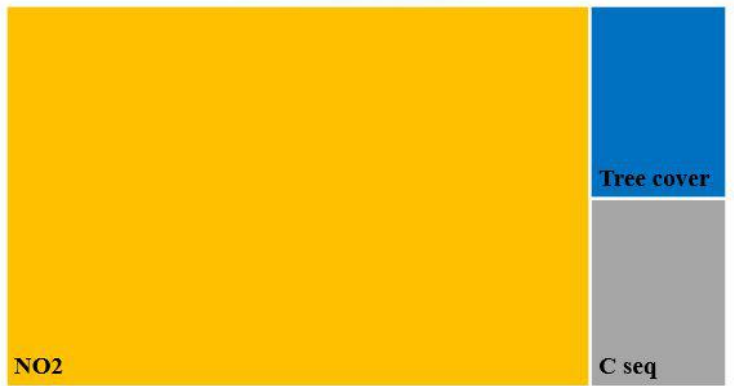

Scenario MPV-A

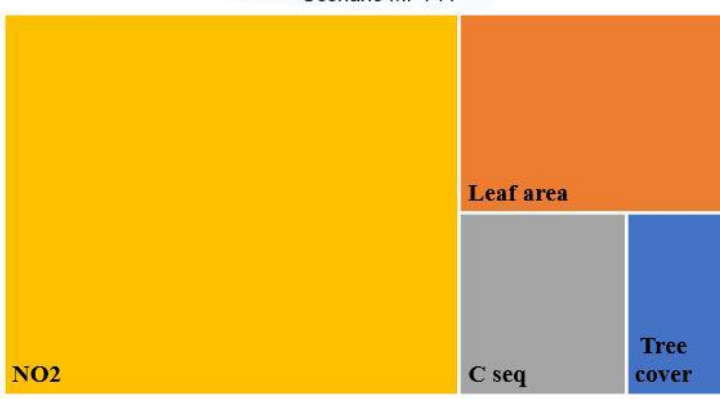

Scenario MPV-A - Forecast

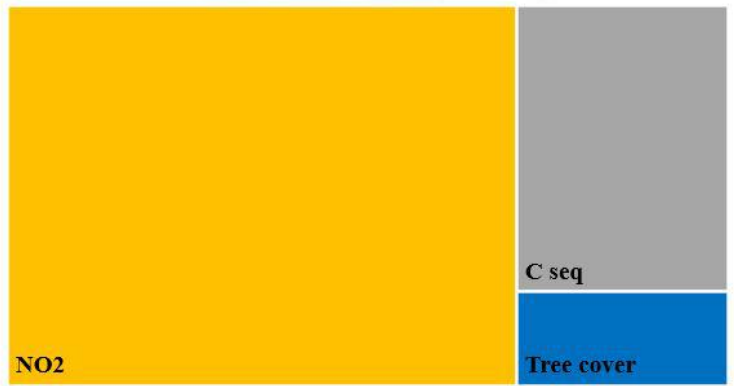

Figure 5. Treemap compares year 0 (above boxes) and 30 (below boxes) of the selected indicators.

\section{Discussion}

The selected software to run the simulation "I-Tree Eco" tested many types of research studies in the last few years, and thus it represents a reliable tool to assess the ES provided by trees and shrubs. However, it requires several inputs to run and give adequate feedback on the urban and peri-urban structures and functions: the optimal solution-recommended in the model guidelines - is to conduct a complete or plot inventory, to collect each needed parameter. In our case study, we had to follow a different approach: as the project is at a starting point, trees and shrubs are still planted. This situation prevented us from collecting data and forced us to extract the needed inputs from the available project documentationa first scenario - and create a new database for the second one leading us to select the ES analysed in our work. To precisely assess the agroecological network's overall impact, we should need much more input (e.g., volume and dimension of each crown), clearly impossible to obtain from a project still ongoing.

The comparison of the two scenarios underlines an interesting difference in the ES provision and the vegetation structure. Each scenario shows our pros and cons that must carefully be evaluated as a requalification choice. Indeed, the project papers' data, referable to the first scenario, showed some limitations. Since the project considers the planting of several hectares, it requires significant economic efforts in materials (plants), both in workforce and labour, to prepare the soil to plant trees and shrubs. It is comprehensible that a project at a starting level may find some difficulties in facing these issues-large land extension in need of requalification and high costs-and therefore choose to plant trees and shrubs in small pots. On the one hand, it reduces costs but on the other hand, causes an initially reduced provision of ES, even if this initial minor provision of ES will ameliorate over the years thanks to annual tree growth.

In the second scenario MPV-A, we wanted to understand which ES provision differences may occur using more developed trees, assuming no budget constraint but balancing the cost with a lower planting density due to a more significant tree dimension (see Table 1).

Consideration about tree size regards, in particular, the ES related to carbon-storage and sequestration. Indeed, the rate of carbon accumulation grows year by year [41], because of the increasing total leaf area, which balances a lower productivity per unit of leaf area. This relatively new scientific assumption-even in the recent past, many researchers [54] 
theorised that after initial growth, the mass growth rate of individual trees declines with increasing tree size, with adverse effects on C storage and sequestration-is confirmed in our results, with a continuous improvement, year by year, of the activity of the tree.

Results show the ES provision thanks to implementing a simple network of trees and shrubs (MPV-H scenario).

An essential key in the ES provision is species-selection. The most successful species related to C sequestration, C storage and avoided run-off within our database is Sambucus nigra. Our results confirmed several studies that showed the potential role of Sambucus nigra in accumulating pollution, from the soil and the air. In particular, Ref. [55] showed the added value of this species in a peri-urban environment as it accumulated $\mathrm{Fe}, \mathrm{Cr}$, and $\mathrm{Zn}$ from the traffic pollution and made these elements available for human consumption as edible flowers. On the other hand, this species suffers from different types of air pollution. Ref. [56] Showed the effectiveness of Sambucus nigra for biomonitoring air pollutants as ozone as it is susceptible to it. Indeed, $\mathrm{O}_{3}$ can be a challenge for plant survival, but particular species could absorb it in the long term [57]. A multi-trait approach and the i-Tree Eco model presented by [57] showed the effectiveness to absorb $\mathrm{O}_{3}$ of other tree species, such as Liriodendron tulipifera, Acer campestre, Acer platanoides and Celtis australis, which are typical of the urban environment-parks and gardens-for their ornamental value too, and not suitable for agroforestry use. This study confirmed our results, showing the highest difference of $\mathrm{O}_{3}$ absorption and $\mathrm{NO}_{2}$ absorption in 30 years. The potential of combining different species of trees—as in a peri-urban agroforestry system-appeared to be the key not only for regulating air pollution but also other regulating services [58,59].

It is also notable that, at year 0 , the higher density of the first scenario balances the smaller dimension of the plants, especially in terms of network structure: tree cover and leaf area have similar values, as the air pollution removal (123 kg/year vs. $128 \mathrm{~kg} /$ year), thanks to the thicker barrier formed by the first scenario.

Overall, the results show the potential impact of the two proposed alternatives. Each one has its advantages, even if it emerges that, in quantitative terms, the second scenario provides higher regulating ES due to bigger plants choice at the implant. However, the first scenario may assure a longer vegetative cycle, and — of course-it represents an affordable solution that links ES provision and economic sustainability.

Another difference regards soil use: the first scenario aims at inserting an initial agroforestry approach, thanks to tree and shrub line between fields, in an area where monoculture is still predominant. The alternative one aims at implementing a stronger agroforestry plan, with trees and shrubs, not only on the hedges of the area and between fields, but inside these fields, occupying half of the overall area. Therefore, this second alternative commits the farmers to adopt a completer agroforestry management of their lands.

The result visualisation obtained with the treemap analysis (Figure 5) allowed us to deeply explore the relationship of the provision of the ES studied in the two alternatives. Furthermore, we can highlight the pros and cons of each requalification choice. The first scenario and the scenario agroforestry represented similar patterns, except for $C$ sequestration. The agroforestry scenario presents higher $C$ sequestration in the present condition and the forecasted scenario in 30 years. This result is coherent with the body of literature that envisioned agroforestry solutions as a sustainable environmental practice for carbon sequestration [60].

Nevertheless, both scenarios will increase biodiversity—by using at the same time several trees and shrubs species-which can lead to multiple benefits and ES, rather than a classic use of few species, or worst, the total absence of trees and shrubs in agricultural fields, which is typical of modern agriculture with a pure monoculture approach, in Milan area too.

Moreover, the MPV project deals with the requalification of a neglected peri-urban area. Beyond environmental aspects, the project has a social and cultural relevance too. This relevance can be proved and measured by looking at various aspects, as new job opportunities in the area due to the establishment of new farms and cultural ES provided 
by the requalification project. These ES — purely immaterial—can also be provided by the network of trees and shrubs, increasing the project's overall importance.

Therefore, although considering a selection of ES, the research shows an effective and replicable strategy to provide ES in urban and peri-urban environments.

The analysis conducted represents a starting point in assessing and evaluating requalification projects' contributions to ecosystem services. This approach could be useful in different areas and cases of study, as well as it could be expanded with the concomitant use of multiple techniques (e.g., software and models) to assess a superior number of ES.

\section{Conclusions}

The study shows that in urban and peri-urban regeneration projects, which often take place at the fringe-zone of our cities, it is possible to increase the provision of ES-and in particular of the regulating ones-thanks to the implementation of GI connected with agroecological projects for implementing networks of trees and shrubs.

This case study in Milan, with the MPV project, aims at requalifying a neglected part of the city, mainly thanks to urban and peri-urban agriculture exploiting the provision of ES thanks to the GI development like a network of trees and shrubs. The research analyses two alternative solutions, with different plantation schemes, tree sizes and densities. Results show that the presence and the future development of this network, in both the configurations, assure several ES, such as carbon sequestration, carbon storage, and an overall air quality improvement. The choice between the two alternatives depends on several aspects, as agricultural management, available time for the requalification and economic resources. The evaluation of trees and shrubs' role was carried out thanks to the specific software-I-Tree Eco- to better understand and analyse ecological, economic and social benefits derived by their presence. The Milano Porta Verde's case study represents challenges and opportunities linked to each requalification project, representing a replicable example in similar conditions. Indeed, thanks to a careful species-selection, it is possible to assure an increasing amount of regulating ES, providing a cost-effective solution and the ongoing requalification project.

Author Contributions: Conceptualization, A.Z., F.A.; methodology, A.Z., F.A.; software, A.Z., F.A.; validation, S.B.; investigation, A.Z., F.A., V.V.; data curation, V.V.; writing-original draft preparation, A.Z., F.A., V.V.; writing-review and editing, S.A., F.O.; supervision, S.B. All authors have read and agreed to the published version of the manuscript.

Funding: This research received no external funding.

Institutional Review Board Statement: Not applicable.

Informed Consent Statement: Not applicable.

Data Availability Statement: The data presented in this study are available on request from the corresponding author.

Acknowledgments: The authors are thankful to Milano Porta Verde project partners for the information and the data provided to conduct the present study. The authors acknowledge support from the University of Milan through the APC initiative.

Conflicts of Interest: The authors declare no conflict of interest.

\section{References}

1. Brondizio, E.S.; Settele, J.; Díaz, S.; Ngo, H.T. IPBES: Global Assessment Report on Biodiversity and Ecosystem Services of the Intergovernmental Science-Policy Platform on Biodiversity and Ecosystem Services; IPBES Secretariat: Bonn, Germany, 2019.

2. UN News Centre. UN Adopts New Global Goals, Charting Sustainable Development for People and Planet by 2030; United Nations Department of Economic and Social Affairs: New York, NY, USA, 2015. [CrossRef]

3. FAO. Guidelines on Urban and Peri-Urban Forestry; FAO Forestry Paper No. 178; Food and Agriculture Organization of the United Nations: Rome, Italy, 2016.

4. Intergovernmental Panel on Climate Change. Fifth Assessment Report (AR5). Available online: https://www.ipcc.ch/assessmentreport/ar5/ (accessed on 1 December 2020). 
5. FAO. State of the World's Forests 2016. Forests and Agriculture: Land-Use Challenges and Opportunities; Food and Agriculture Organization of the United Nations: Rome, Italy, 2016.

6. UN Habitat. Cities and Climate Change: Global Report on Human Settlements; United Nations Human Settlements Programme: Nairobi, Kenya, 2011.

7. UN. Transforming Our World: The 2030 Agenda for Sustainable Development, A/RES/70/1; United Nations: New York, NY, USA, 2015.

8. FAO. FAO Framework for the Urban Food Agenda; Food and Agriculture Organization of the United Nations: Rome, Italy, 2019. [CrossRef]

9. De Valck, J.; Beames, A.; Liekens, I.; Bettens, M.; Seuntjens, P.; Broekx, S. Valuing urban ecosystem services in sustainable brownfield redevelopment. Ecosyst. Serv. 2019, 35, 139-149. [CrossRef]

10. Interregeurope 2020, Urban Ecosystems: The Importance of Green Infrastructure and Nature-Based Solutions for the Development of Sustainable Cities. A Policy Brief from the Policy Learning Platform on Environment and Resource Efficiency. 2020. Available online: https: / / euagenda.eu/upload/publications/untitled-291508-ea.pdf (accessed on 15 December 2020).

11. Miller, S.M.; Montalto, F.A. Stakeholder perceptions of the ecosystem services provided by Green Infrastructure in New York City. Ecosyst. Serv. 2019, 37, 100928. [CrossRef]

12. New York City Department of Environmental Protection (NYC DEP). NYC Green Infrastructure Plan: A Sustainable Strategy for Clean Waterways. 2010. Available online: https:/ / www1.nyc.gov/site/dep/water/green-infrastructure.page (accessed on 9 December 2020).

13. Philadelphia Water Department (PWD). Green Cities Clean Waters (Amended). 2011. Available online: http://www. phillywatersheds.org/doc/GCCW_AmendedJune2011_LOWRES-web.pdf (accessed on 9 December 2020).

14. City of Toronto (COT). Toronto Municipal Code Chapter 492, Green Roofs. Toronto, CA. 2013. Available online: http://www. toronto.ca/legdocs/municode/1184_492.pdf (accessed on 9 December 2020).

15. Sewage and Water Board of New Orleans (SWB NO). Green Infrastructure Plan. 2014. Available online: https: / www.swbno. org/documents/environmental/greeninfrastructure/GreenInfrastructurePlan.pdf (accessed on 9 December 2020).

16. De Sousa, M.R.C.; Miller, S.; Dorsch, M.; Montalto, F.A. Green Infrastructure as Climate Change Resiliency Strategy in Jamaica Bay_Prospects for Resilience; Springer: Berlin/Heidelberg, Germany, 2016.

17. United States Environmental Protection Agency, Clean Water Act 2018. Available online: https:/ /www.govinfo.gov/content/ pkg/USCODE-2018-title33/pdf/USCODE-2018-title33-chap26.pdf (accessed on 1 December 2020).

18. European Environment Agency. Air Quality in Europe-2013 Report; EEA Report 9/2013; Publications Office of the European Union: Copenhagen, Denmark, 2013.

19. Escobedo, F.J.; Wagner, J.E.; Nowak, D.J.; De la Maza, C.L.; Rodrı'guez, M.; Crane, D.E. Analysing the cost effectiveness of Santiago, Chile's policy of using urban forests to improve air quality. J. Environ. Manag. 2018, 86, 148-157. [CrossRef]

20. Baró, F.; Chaparro, L.; Gomez-Baggethun, E.; Langemeyer, J.; Nowak, D.; Terradas, J. Contribution of Ecosystem Services to Air Quality and Climate Change Mitigation Policies: The Case of Urban Forests in Barcelona, Spain. Ambio 2014, 43, 466-479. [CrossRef] [PubMed]

21. Kiss, M.; Takacs, A.; Pogacsas, A. The role of ecosystem services in climate and air quality in urban areas: Evaluating carbon sequestration and air pollution removal by street and park trees in Szeged (Hungary). Morav. Geogr. Rep. 2015, 23, 36-46. [CrossRef]

22. Manes, F.; Marandoa, F.; Capotorti, G.; Blasi, C.; Salvatori, E.; Fusaroa, L.; Ciancarella, L.; Mircea, M.; Marchetti, M.; Chirici, G.; et al. Regulating Ecosystem Services of forests in ten Italian Metropolitan Cities: Air quality improvement by PM10 and O3 removal. Ecol. Indic. 2016, 67, 425-440. [CrossRef]

23. Shibu, J. Agroforestry for ecosystem services and environmental benefits: An overview. Agrofor. Syst. 2009, 76, 1-10. [CrossRef]

24. Jones, S.; Somper, C. The role of green infrastructure in climate change adaptation in London. Geogr. J. 2014, 180, 191-196. [CrossRef]

25. Elmqvist, T.; Setala, H.; Handel, S.N.; van der Ploeg, S.; Aronson, J.; de Groot, R. Benefits of restoring ecosystem services in urban areas. Ecosyst. Serv. 2015, 14, 101-108. [CrossRef]

26. Pulighe, G.; Fava, G.; Lupia, F. Insights and opportunities from mapping ecosystem services of urban green spaces and potentials in planning. Ecosyst. Serv. 2016, 22, 1-10. [CrossRef]

27. Semeraro, T.; Aretano, R.; Pomes, A. Green Infrastructure to Improve Ecosystem Services in the Landscape Urban Regeneration. IOP Conf. Ser.: Mater. Sci. Eng. 2017, 245, 082044. [CrossRef]

28. Di Marino, M.; Lapintie, K. Exploring the concept of green infrastructure in urban landscape. Experiences from Italy, Canada and Finland. Landsc. Res. 2018, 43, 139-149. [CrossRef]

29. Dendoncker, N.; Boeraeve, F.; Crouzat, E.; Dufrêne, M.; König, A.; Barnaud, C. How can integrated valuation of ecosystem services help understanding and steering agroecological transitions? Ecol. Soc. 2018, 23, 12. [CrossRef]

30. Estreguil, C.; Dige, G.; Kleeschulte, S.; Carrao, H.; Raynal, J.; Teller, A. Strategic Green Infrastructure and Ecosystem Restoration: Geospatial Methods, Data and Tools, EUR 29449 EN; Publications Office of the European Union: Luxembourg, 2019; ISBN 978-92-7997294-2. [CrossRef]

31. FAO. Advancing Agroforestry on the Policy Agenda 2013. Available online: http://www.fao.org/forestry/agroforestry/80338/ en/ (accessed on 29 November 2020). 
32. Braat, L.C.; Groot, R.D. The ecosystem services agenda: Bridging the world soft natural science and economics, conservation and development, and public and private policy. Ecosyst. Serv. 2017, 1, 4-15. [CrossRef]

33. Daily, G.C.; Matson, P.A. Ecosystem services: From theory to implementation. Proc. Natl. Acad. Sci. USA 2008, 105, 9455-9456. [CrossRef]

34. Daily, G.C.; Polasky, S.; Goldstein, J.; Kareiva, P.M.; Mooney, H.A.; Pejchar, L.; Ricketts, T.H.; Salzman, J.; Shallenberger, R. Ecosystem services in decision making: Time to deliver. Front. Ecol. Environ. 2009, 7, 21-28. [CrossRef]

35. Ruckelshaus, M.; McKenzie, E.; Tallis, H.; Guerry, A.; Daily, G.; Kareiva, P.; Polasky, S.; Ricketts, T.; Bhagabati, N.; Wood, S.A.; et al. Note from the field: Lessons learned from using ecosystem service approaches to informreal-worlddecisions. Ecol. Econ. 2015, 115, 11-21. [CrossRef]

36. Bagstad, K.J.; Semmens, D.J.; Waage, S.; Winthrop, R. A comparative assessment of decision-support tools for ecosystem services quantification and valuation. Ecosyst. Serv. 2013, 5, 27-39. [CrossRef]

37. Posner, S.; Verutes, G.; Koh, I.; Denu, D.; Ricketts, T. Global use of ecosystem service models. Ecosyst. Serv. 2016, 17, $131-141$. [CrossRef]

38. European Rural Innovation Ambassadors. Available online: https:/ /liaison2020.eu/abmassadors/milano-porta-verde/ (accessed on 15 December 2020).

39. Nerlich, K.; Graeff-Hönninger, S.; Claupein, W. Erratum to: Agroforestry in Europe: A review of the disappearance of traditional systems and development of modern agroforestry practices, with emphasis on experiences in Germany. Agroforest. Syst. 2013, 87, 1211. [CrossRef]

40. Caputo, P.; Zagarella, F.; Cusenza, M.A.; Mistretta, M.; Cellura, M. Energy-environmental assessment of the UIA-OpenAgri case study as urban regeneration project through agriculture. Sci. Total Environ. 2020, 729, 138819. [CrossRef]

41. ISPRA, Stato Dell'ambiente, 82/2018, ISBN: 978-88-448-0926-3. Available online: https://www.isprambiente.gov.it/it/ pubblicazioni/stato-dellambiente/xiv-rapporto-qualita-dell2019ambiente-urbano-edizione-2018 (accessed on 15 December 2020).

42. Nowak, D.J.; Crane, D.E. The Urban Forest Effects (UFORE) Model: Quantifying urban forest structure and functions. In Integrated Tools for Natural Resources Inventories in the 21st Century, Proceedings of the IUFRO Conference, Gen. Tech. Rep. NC-212, Boise, ID, USA, 16-20 August 1998; Hansen, M., Burk, T., Eds.; USS Department of Agriculture, Forest Service, North Central Research Station: St. Paul, MN, USA, 2000; pp. 714-720.

43. Baldocchi, D. A multi-layer model for estimating sulfur dioxide deposition to a deciduous oak forest canopy. Atmos. Environ. 1988, 22, 869-884. [CrossRef]

44. Baldocchi, D.D.; Hicks, B.B.; Camara, P. A canopy stomatal resistance model for gaseous deposition to vegetated surfaces. Atmos. Environ. 1987, 21, 91-101. [CrossRef]

45. Lovett, G.M. Atmospheric deposition of nutrients and pollutants in North America: An ecological perspective. Ecol. Appl. 1994, 4, 629-650. [CrossRef]

46. Zinke, P.J. Forest interception studies in the United States. In Forest Hydrology; Sopper, W.E.E., Lull, H.W., Eds.; Pergamon Press: Oxford, UK, 1967; pp. 137-161.

47. Nowak, D.J.; Hirabayashi, S.; Bodine, A.; Hoehn, R. Modeled PM 2.5 removal by trees in ten USS cities and associated health effects. Environ. Pollut. 2013, 178, 395-402. [CrossRef] [PubMed]

48. Abdollahi, K.K.; Ning, Z.H.; Appeaning, A. Global Climate Change and the Urban Forest; GCRCC and Franklin Press: Baton Rouge, LA, USA, 2000; p. 77.

49. Nowak, D.J. Atmospheric carbon dioxide reduction by Chicago's urban forest. In Chicago's Urban Forest Ecosystem: Results of the Chicago Urban Forest Climate Project. Gen. Tech. Rep. NE-186; McPherson, E.G., Nowak, D.J., Rowntree, R.A., Eds.; USS Department of Agriculture, Forest Service, Northeastern Forest Experiment Station: Radnor, PA, USA, 1994; pp. 83-94.

50. Nowak, D.J.; Hoehn, R.; Crane, D. Oxygen production by urban trees in the United States. Arboric. Urban For. 2007, 33, 220-226.

51. Steenberg, J.W.N.; Millward, A.A.; Nowak, D.J.; Robinson, P.J.; Ellis, A. Forecasting Urban Forest Ecosystem Structure, Function, and Vulnerability. Environ. Manag. 2017, 59, 373-392. [CrossRef]

52. Shneiderman, B. Tree visualisation with tree-maps: 2-d space-filling approach. ACM Trans. Graph. (TOG) 1992, 11,92-99. [CrossRef]

53. Gorodov, E.Y.E.; Gubarev, V.V.E. Analytical review of data visualisation methods in application to big data. J. Electr. Comput. Eng. 2013, 2013, 969458.

54. Stephenson, N.; Das, A.; Condit, R.; Russo, S.E.; Baker, P.J.; Beckman, N.G.; Coomes, D.A.; Lines, E.R.; Morris, W.K.; Rüger, N.; et al. Rate of tree carbon accumulation increases continuously with tree size. Nature 2014, 507, 90-93. [CrossRef] [PubMed]

55. Topolska, J.; Kostecka-Gugała, A.; Ostachowicz, B.; Latowski, D. Selected metal content and antioxidant capacity of Sambucus nigra flowers from the urban areas versus soil parameters and traffic intensity. Environ. Sci. Pollut. Res. 2020, $27,668-677$. [CrossRef] [PubMed]

56. Cano, I.; Calatayud, V.; Cerveró, J.; Sanz, M.J. Ozone effects on three Sambucus species. Environ. Monit. Assess. 2000, $128,83-91$. [CrossRef] [PubMed]

57. Baraldi, R.; Chieco, C.; Neri, L.; Facini, O.; Rapparini, F.; Morrone, L.; Rotondi, A.; Carriero, G. An integrated study on air mitigation potential of urban vegetation: From a multi-trait approach to modeling. Urban For. Urban Green. 2019, 41, 127-138. [CrossRef] 
58. Borelli, S.; Conigliaro, M.; Quaglia, S.; Salbitano, F. Urban and Peri-urban agroforestry as multifunctional land use. In Agroforestry; Springer: Singapore, 2017; pp. 705-724.

59. Brown, S.E.; Miller, D.C.; Ordonez, P.J.; Baylis, K. Evidence for the impacts of agroforestry on agricultural productivity, ecosystem services, and human well-being in high-income countries: A systematic map protocol. Environ. Evid. 2018, 7, 24. [CrossRef]

60. Abbas, F.; Hammad, H.M.; Fahad, S.; Cerdà, A.; Rizwan, M.; Farhad, W.; Ehsan, S.; Bakhat, H.F. Agroforestry: A sustainable environmental practice for carbon sequestration under the climate change scenarios-A review. Environ. Sci. Pollut. Res. 2017, 24, 11177-11191. [CrossRef] 